\title{
“CONHECE AQUELA DO DELEGADO?”: PIADAS SOBRE OS HOMENS DA LEI NO JORNAL SANTUARIO DA TRINDADE (1922-1931)
}

\author{
"Do you Know that one about \\ the Police Chief?": Jokes about \\ Men of Law in the Newspaper \\ “¿Sabes aquella del delegado?”: \\ bromas sobre hombres de derecho \\ en el periódico \\ Santuario da Trindade (1922-1931) Santuario da Trindade (1922-1931)
}

\author{
Andréia Márcia de Castro Galvão* \\ Universidade do Minho, Programa Doutoral em Modernidades Comparadas: \\ Literaturas, Artes e Culturas, Campus Gualtar, Braga, Portugal \\ Eliézer Cardoso de Oliveira** \\ Universidade Estadual de Goiás, Mestrado Interdisciplinar em \\ Território e Expressões Culturais do Cerrado, Anápolis, GO, Brasil
}

\begin{abstract}
Resumo: $\mathrm{O}$ artigo analisa a representação sobre autoridades policiais e jurídicas em Goiás, nas primeiras décadas do século XX, por meio de anedotas presentes no jornal católico Santuario da Trindade, em circulação de 1922 a 1931. Alguns subsídios teóricos oferecidos por Mikhail Bakhtin, como a ideia de carnavalização do mundo e realismo grotesco, são essenciais para pensar o humor presente nesse jornal, uma vez que tais anedotas ridicularizavam a atuação da força policial, demonstrando o que o autor caracterizou como a irreverência da cultura popular em relação às instituições sérias. Nesse sentido, essas piadas são percebidas como produções discursivas das camadas populares goianas, e passíveis de variadas interpretações: podem ser compreendidas não apenas como instrumentos de humor, grande amenizador das tensões cotidianas, mas também como expoentes de uma mentalidade coletiva, revelando certos modos de pensar da cultura sertaneja em relação à atuação jurídica e policial em Goiás.
\end{abstract}

Palavras-chave: Cultura popular. Jornal Santuario da Trindade. Bakhtin. Atuação policial. Anedotas.

\begin{abstract}
The paper analyzes the representation of police and juridical authorities in Goiás, Brazil during the first decades of the twentieth century through anecdotes presented in the Catholic newspaper Santuario da Trindade, which circulated from 1922 to 1931. Some theoretical notions offered by Mikhail Bakhtin, such as the ideas of "world carnivalization" and "grotesque realism", are essential to ponder on the humor present in this newspaper, since those anecdotes mocked the police force's action, demonstrating what the author characterized as the irreverence of the popular culture in relation to serious institutions. In this sense, those jokes are discursive productions from the popular order of Goiás and they are susceptible to assorted interpretations. That is to say they can be understood not only as instruments of humor - a great way to ease up daily tensions - but also as exponents of a collective mentality, which reveals certain ways of thinking of the country culture regarding the juridical and police actions in Goiás.
\end{abstract}

Keywords: Popular culture. Santuario da Trindade newspaper. Bakhtin. Police action. Anecdotes.

\footnotetext{
* Mestre em Ciências Sociais e Humanidade pelo Mestrado Interdisciplinar em Território e Expressões Culturais no Cerrado da Universidade Estadual de Goiás - Anápolis. ORCID: https://orcid.org/00000003-3454-6709; E-mail: oidegas@gmail.com.

${ }^{* *}$ Doutor em Sociologia pela Universidade de Brasília. Professor da Graduação em História e do Mestrado interdisciplinar em Território e Expressões Culturais do Cerrado. ORCID: https://orcid.org/0000-00017763-7454. E-mail: ezi@uol.com.br.
} 
Resumen: El artículo analiza la representación sobre autoridades policiales y jurídicas en Goiás, en las primeras décadas del siglo XX, por medio de bromas presentes en el periódico católico Santuario da Trindade, en circulación de 1922 hacia 1931. Algunos subsidios teóricos ofrecidos por Mijaíl Bajtín, como la idea de carnavalización del mundo y realismo grotesco, son esenciales para pensar el humor presente en ese periódico, pues tales bromas ridiculizaban la actuación de la fuerza policial, demostrando lo que el autor caracterizó como irreverencia de la cultura popular con relación a instituciones serias. Al respecto, esas bromas son percibidas como producciones discursivas de los estratos populares de Goiás, y susceptible de variadas interpretaciones: pueden ser comprendidas no apenas como instrumentos de humor, gran amenizador de las tensiones cotidianas, también como exponentes de una mentalidad colectiva, revelando ciertos modos de pensar de la cultura sertaneja con relación a actuación jurídica y policial en Goiás.

Palabras clave: Cultura popular. Periódico Santuario da Trindade. Bajtín. Actuación policial. Bromas.

\section{INTRODUÇÃO}

Geraldo Policiano Nogueira (1918-1993), conhecido popularmente como Geraldinho, foi um contador de causos muito conhecido em Goiás. Com uma linguagem tipicamente caipira, Geraldinho tornou-se um verdadeiro símbolo cultural, participando na década de 1980 de programas televisivos, radiofônicos e shows de teatro. Em uma de suas famosas histórias, o Causo do soldado, Geraldinho relata suas desventuras, quando ele e um grupo de amigos, reunidos em um bar, são vítimas da violência e truculência da polícia goiana, levando-o a afirmar "eu nunca fui de combinar com o tal sordado não". A aversão de Geraldinho aos policiais não é algo isolado, mas uma presença constante nas representações da cultura popular goiana. Nesse sentido, muitos outros exemplos poderiam ser citados, como aquele do conto A enxada, do escritor Bernardo Élis, no qual a polícia representava desconfiança e temor aos olhos da personagem: "Soldado para ela tinha parte com o Sujo. Era uma nação de gente que metia medo pela ruindade. Soldado não podia ser filho de Deus" (ÉLIS, 2003, p. 93).

Tal representação negativa dos policiais na cultura popular pode ser explicada, ao menos em parte, pelo modo autoritário e violento com que foi constituído o aparelho repressivo em Goiás. A polícia e os coletores de impostos representavam o lado mais visível da interferência do Estado na vida privada dos camponeses. Em meio a dificuldades de se operacionalizar a monopolização da violência, a força policial usava uma força bruta desproporcional contra a população. Na luta da polícia contra os jagunços dos coronéis ou contra bandoleiros armados, a população ficava perigosamente em meio ao fogo cruzado, ao ponto de um dos contemporâneos dessas disputas afirmar que "soldados ou paisanos, depois de sua passagem, deixavam a desolação acariciando a face da terra" (XAVIER apud PALACIN, 1990, p. 77). Com isso, constituiu-se uma memória coletiva que representou negativamente a polícia no imaginário popular ${ }^{1}$.

\footnotetext{
${ }^{1} \mathrm{O}$ imaginário constitui-se num dos temas mais recorrentes nas ciências humanas dos últimos anos. Para os propósitos deste artigo, considerou-se satisfatória a definição proposta por Sandra Pesavento (1995, p. 24): “O imaginário é [...] representação, evocação, simulação, sentido e significado, jogo de espelhos onde o ‘verdadeiro' e o aparente se mesclam, estranha composição onde a metade visível evoca qualquer coisa de ausente e difícil de perceber". Essa definição permite compreender a existência de determinadas representações, como a da visão negativa da polícia em Goiás, sem a necessidade de postular sua verdade ou falsidade. O importante é que essa representação imaginária ganhou força suficiente para se tornar um elemento constituinte do que Maurice Halbwachs (2003) denomina memória coletiva.
} 
Contudo, a irreverência das camadas populares não ficou passiva diante dos desmandos do aparelho repressivo do Estado. E, nesse sentido, policiais, delegados, militares e juízes passaram a ser alvo de chacotas em inúmeras anedotas ${ }^{2}$ que circulavam entre a população goiana. O objetivo deste artigo é analisar um conjunto de piadas presentes no jornal Santuario da Trindade e tomá-las como exemplo do riso irreverente segundo Mikhail Bakhtin.

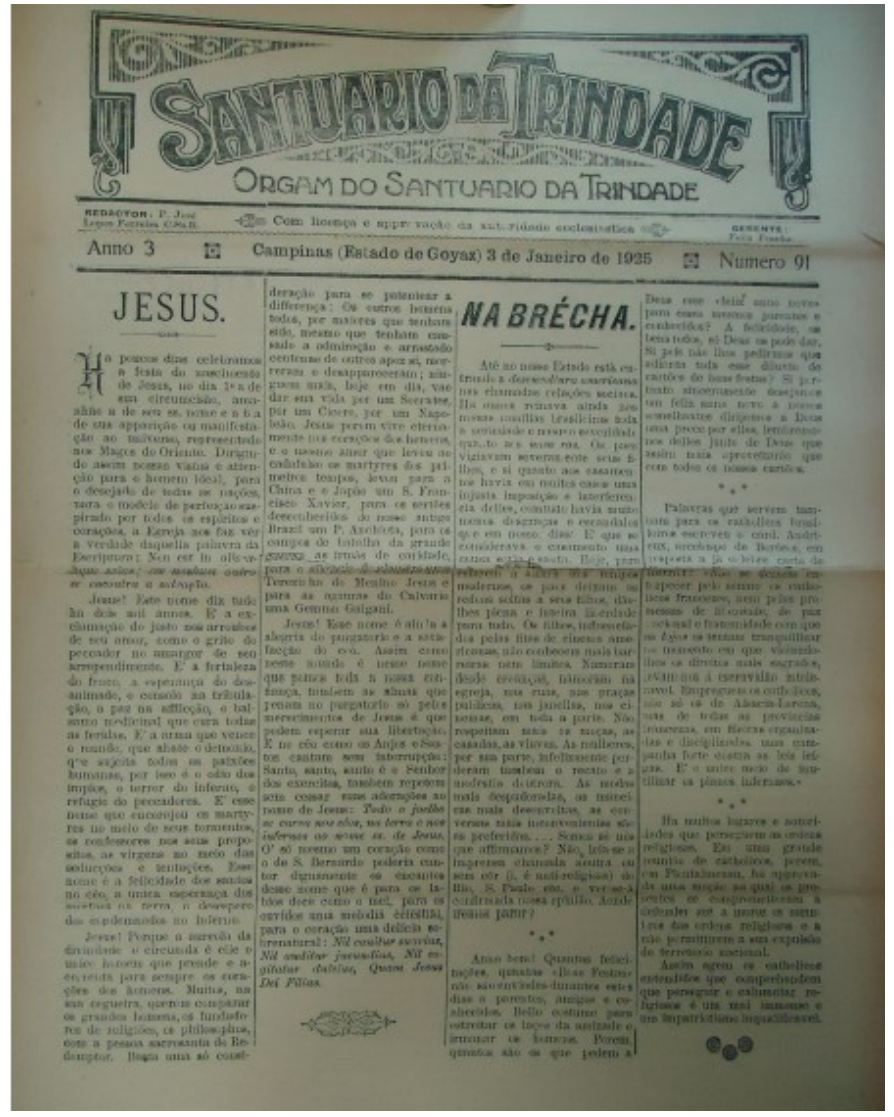

Figura 1 - Fotografia da primeira página do jornal Santuário de Trindade, edição de 3 de Janeiro de 1925

O Santuario da Trindade foi fundado na cidade de Campinas (hoje, bairro de Goiânia) por membros da Congregação do Santíssimo Redentor - os redentoristas ${ }^{3}$. Ele teve o propósito explícito de fortalecer a fé e combater os inimigos da Igreja Católica, nomeadamente o protestantismo, o espiritismo e a maçonaria, que vinham cada vez mais ganhando força no estado ${ }^{4}$.

\footnotetext{
${ }^{2}$ Não obstante alguns autores importantes, como Freud (1905), façam distinção entre "piada", "chiste", "anedota" e "pilhéria", neste artigo as diversas denominações serão utilizadas indistintamente, todas a denotar uma pequena história, real ou fictícia, que intenciona provocar o riso.

${ }^{3}$ Os primeiros redentoristas chegaram em Goiás em 1894 a convite do bispo dom Eduardo Duarte Silva. A vinda de religiosos estrangeiros para o Brasil era um componente importante do que ficou conhecido como "romanização" da Igreja católica.

${ }^{4}$ Esse propósito combativo do jornal fica evidente, por exemplo, numa matéria exaltando a construção do Monumento do Cristo Redentor, concebido como "a expressão sublime de um esforço heroico em tempo 
O jornal circulou de $1^{\circ}$ de julho de 1922 a $1^{\circ}$ de julho de 1931 , primeiramente em publicações quinzenais, e a partir do segundo ano em números semanais, somando um total de 402 edições. Em relação a seu formato, era composto de quatro páginas, cada uma delas dividida em quatro colunas. A primeira matéria era quase sempre escrita por seu diretor e trazia geralmente um assunto de interesse religioso. Era recheado de notícias regionais, nacionais e internacionais; os textos literários normalmente vinham na seção "Leituras Amenas", onde também se publicava vez por outra a biografia de algum santo ou de personagem religioso. As poucas imagens veiculadas eram, salvo alguma exceção, parte dos anúncios de propaganda, na quarta página. As piadas que se constituíram fonte para a pesquisa estavam presentes numa seção intitulada Anecdotas, geralmente na terceira página.

Por veicular textos literários, poesia e a pequena seção de anedotas, constitui um exemplo de jornal que começou a circular a partir do final do século XIX. Sobre essa inovação jornalística, Olavo Bilac (apud SALIBA, 2002, p. 38) comenta: "jornal leve e barato, verdadeiro espelho da alma popular, síntese e análise das suas opiniões, das suas aspirações, das suas conquistas, do seu progresso".

As narrativas humorísticas presentes no jornal Santuario da Trindade são materiais riquíssimos de análise, pois abordam de modo irreverente diferentes tipos sociais: médicos, mulheres, maridos, caipiras, agentes da lei (tema deste artigo), dentre outros. As piadas não continham marcas de autoria e nem mesmo identificação de procedência. Entretanto, algumas suposições puderam ser feitas: foram copiadas de outros jornais? É verdade que havia grande circulação de periódicos na época; contudo, somente alguns deles veiculavam anedotas, o que dificultaria (ou mesmo impossibilitaria) sua constante presença na folha em questão. Foram colhidas pelos missionários redentoristas nas andanças pela diocese? Essa ideia, embora interessante, parece também pouco factível, uma vez que a coleta sistemática e a transcrição do grande número de piadas ao longo do tempo veiculadas (recorda-se que cada edição continha de duas a quatro delas) parece incompatível com a falta de tempo ligada às dificuldades e ao excesso de afazeres durante essas viagens. Com efeito, várias vezes foi narrado nos relatórios anuais da Congregação que tempo não havia nem para os trabalhos essenciais e improrrogáveis. Ou ainda, foram retiradas de algum livro de piadas? Essa hipótese parece plausível; entretanto, se se tratasse de uma compilação única (livro, almanaque humorístico etc.), resultaria estranho que uma mesma anedota fosse repetida com algumas palavras diversas, como ocorreu variadas vezes. Ou seja, parece inusitado que em um livro de piadas houvesse piadas repetidas. Como é possível perceber, cada uma das hipóteses levantadas encontra ao menos um argumento que a inviabiliza. Em todo caso, até que esse mistério ganhe uma resposta, todas essas possibilidades - e outras mais - podem ser consideradas minimamente aceitáveis.

Em relação à inserção deliberada de humor no Santuario da Trindade na seção Anecdotas, acredita-se que tenha representado um atrativo do periódico na medida em

de desanimo, de um protesto de fé no tempo em que o atheismo [maçonaria] e o protestantismo e o espiritismo uniram suas forças para atacarem a Religião do povo brasileiro." (SANTUARIO DA TRINDADE, 1923, N. 38, p. 1). Da mesma forma que o monumento, o Santuario se via como o símbolo contra as ameaças ao catolicismo brasileiro. 
que brincou com as tensões do cotidiano, e "por meio de uma linguagem fluida e jocosa, pode ter contribuído, quer-se supor, para uma derrisão quase que libertadora, ou ao menos, desatadora de alguns nós da existência" (GALVÃO, 2015, p. 70). Sob essa óptica, o interessante das piadas é que elas podem ser concebidas como documentos da cultura e ideologia popular, "são uma espécie de sintoma, [...] relativas a domínios discursivos 'quentes"' e, também, são "quase sempre veículo de um discurso proibido, subterrâneo, não oficial" mas que reproduzem discursos que já circulavam de alguma outra forma no cotidiano da população, como assinala Possenti (1998, p. 25-6). O que significa afirmar que, nesse caso, quando policiais, delegados e juízes tornavam-se objeto de galhofa e zombaria, nas anedotas do jornal, isso constituía uma resposta às possíveis situações de conflito e abuso de poder presentes na sociedade da época.

Portanto, considerar as piadas sobre os homens da lei presentes no Santuario da Trindade como produções discursivas das camadas populares goianas significa abrir um amplo leque de interpretação, que possibilita compreendê-las não apenas como instrumento de humor, mas também como expoentes de uma mentalidade coletiva, revelando certos modos de pensar da cultura sertaneja em relação à atuação jurídica e policial em Goiás.

\section{BAKHTIN E O RISO IRREVERENTE}

As teorias sobre o humor e o riso de Mikhail Bakhtin, na obra clássica $A$ cultura popular na Idade Média e no Renascimento: o contexto de François Rabelais, de 1965, corroboram a ideia do humor como amenizador das tensões cotidianas. Alguns subsídios teóricos oferecidos pelo autor, como a ideia de carnavalização do mundo e realismo grotesco, são essenciais para se pensar o humor presente no jornal Santuario da Trindade.

Bakhtin (1999) ressalta a importância do carnaval e do riso para uma compreensão da cultura popular da Idade Média e do Renascimento. O carnaval, dentre outras manifestações consagradas pela tradição, possuía elementos dedicados ao cômico e oferecia uma visão diversa de mundo, do homem e das relações humanas, sob um viés não oficial. As festas oficiais da Igreja e do Estado feudal não criavam uma segunda vida, ao contrário, colaboravam para consagrar a estabilidade, a imutabilidade, fortificar o regime em vigor e suas regras: "hierarquias, valores, normas e tabus religiosos, políticos e morais correntes" (BAKHTIN, 1999, p. 8). Assim, as desigualdades e a hierarquia eram destacadas intencionalmente, e títulos, graus e funções eram apresentados, reservando a cada um seu lugar de direito. O carnaval, por sua vez, era a festa do tempo futuro (ainda incompleto), ele libertava temporariamente da verdade dominante e do regime vigente, de todas as "relações hierárquicas, privilégios, regras e tabus" (1999, p. 8). Essa liberação da hierarquia favoreceu a criação de uma linguagem própria da praça pública com vocabulário e gestos específicos, capazes de expressar as formas e símbolos do carnaval, aproximando os indivíduos. Tal linguagem caracteriza-se pela "lógica original das coisas 'ao avesso', 'ao contrário', das permutações constantes do alto e do baixo ('a roda'), da face e do traseiro, e pelas diversas formas de paródias, travestis, degradações, profanações, coroamentos e destronamentos bufões" (1999, p. 10). O riso na festa popular escarnece dos próprios burladores. 
Vale lembrar que nas grandes cidades europeias as celebrações carnavalescas poderiam durar três meses por ano. Essa visão carnavalesca marcava de forma indelével o pensamento e a visão de mundo do homem medieval, como por exemplo, impunha-lhe renegar em certa medida sua condição social ("como monge, clérigo ou erudito") e a ver o mundo sob a óptica cômica e carnavalesca, ressalta o autor. Nesse sentido, também os eclesiásticos, teólogos e sábios etc. permitiam-se certas distrações e muitos deles escreviam tratados cômicos e paródias em latim. Durante o longo período de desenvolvimento da literatura cômica medieval, ela sofreu grandes mudanças em seu gênero e estilística. Essa literatura foi amplamente difundida, chegando às camadas mais elevadas do pensamento culto religioso por meio de manuscritos em que os ritos oficiais da Igreja eram descritos sob um ponto de vista cômico. Igualmente diversificada e rica era a literatura cômica em língua vulgar, na qual predominavam as paródias e travestis laicos que zombavam do "regime feudal e sua epopeia heroica" (BAKHTIN, 1999, p. 13). $\mathrm{O}$ autor chama a atenção para o fato de que muitas expressões e palavras injuriosas e ainda grosserias blasfematórias dirigidas às divindades ganharam um tom ambivalente, devido à liberdade vivida no período; elas "degradavam e mortificavam, simultaneamente regeneravam e renovavam” (1999, p. 15). Também os juramentos e as obscenidades, excluídas da linguagem oficial, renovavam-se na linguagem familiar do cômico carnavalesco.

Já o realismo grotesco caracteriza-se, por sua vez, pelo rebaixamento, vale dizer, pela transferência ao nível do material e corporal do que é espiritual, ideal, elevado e abstrato. Sobre esse aspecto, Bakhtin (1999) expõe como exemplo as paródias latinas medievais com trechos bíblicos, detalhando os aspectos degradantes, ou ainda o deslocamento ao plano material e corporal dos ritos e cerimônias solenes. Cita a gramática jocosa - muito popular nos ambientes escolares cultos medievais - cujas categorias gramaticais, formas verbais e casos, dentre outros, eram transferidas ao plano corporal e material. O realismo grotesco rebaixa, aproxima da terra e corporifica; o "riso popular que organiza todas as formas do realismo grotesco foi sempre ligado ao baixo material e corporal. O riso degrada e materializa" (1999, p. 18).

Em resumo:

\begin{abstract}
O riso e a visão carnavalesca do mundo, que estão na base do grotesco, destroem a seriedade unilateral e as pretensões de significação incondicional e intemporal e liberam a consciência, o pensamento e a imaginação humana, que ficam assim disponíveis para o desenvolvimento de novas possibilidades. Daí que uma certa "carnavalização" da consciência precede e prepara sempre as grandes transformações, mesmo no domínio científico. (BAKHTIN, 1999, p. 43)
\end{abstract}

E, embora a obra Bakhtin refira-se a manifestações da cultura cômica popular de um passado relativamente remoto, ela oferece possibilidades para se pensar também sobre temáticas culturais mais recentes. Assim, as teorias que anunciam um mundo sob uma óptica carnavalizada, com a inversão simbólica das hierarquias, a ambivalência do riso, da noção de vida, morte e tempo, presentes na estética do realismo grotesco, são utilizadas neste estudo a fim de tentar compreender o humor e o riso da seção de anedotas do jornal católico Santuario da Trindade. Afinal, até mesmo dentro da igreja o riso era permitido em algum momento, como na tradição do risus paschalis, prática que persistiu na Europa até o século XVI. 
A tradição antiga permitia o riso e as brincadeiras licenciosas no interior da igreja na época da Páscoa. Do alto do púlpito, o padre permitia-se toda espécie de histórias e brincadeiras a fim de obrigar os paroquianos, após um longo jejum e uma longa abstinência, a rir com alegria e esse riso era um renascimento feliz. Essas brincadeiras e histórias alegres de tipo carnavalesco referiam-se essencialmente à vida material e corporal. $\mathrm{O}$ riso era autorizado, da mesma forma que o eram a carne e a vida sexual (interditas durante o jejum). (BAKHTIN, 1999 , p. 68, grifo do autor)

Mesmo reconhecendo certa fluidez entre a cultura popular e a cultura erudita, Bakhtin distinguiu a cultura popular como sendo marcada pela transgressão dos limites, enquanto que aquela oficial era caracterizada pela seriedade. Nesse sentido, os agentes da lei precisavam ser sérios, solenes e sisudos para serem respeitados, assim como os padres e os homens de Estado. A cultura popular, em contrapartida, transformava o sério da cultura oficial em um riso debochado e carnavalesco.

\section{A FORÇA PÚBLICA DE GOIÁS NO INÍCIO DO SÉCULO XX}

À época da circulação do Santuario da Trindade o Brasil ainda vivia uma situação bastante complexa no quesito Força Pública. Em Goiás, por exemplo, ela era composta por poucos homens e, em sua maioria, bastante despreparados. Assim, o número reduzido, o vasto território, os precários meios de transporte e o índice populacional (511.519 pessoas, de acordo com o senso de 1920) eram fatores que tornavam sofríveis as condições de trabalho dos agentes da lei, e mais, a situação era agravada por certa aversão popular a esta profissão.

Sobre a ojeriza da sociedade goiana à polícia, Eliézer C. de Oliveira (2012) relata que esta é uma representação coletiva dos séculos XIX e XX, muito bem apresentada pela literatura regional. Contos e romances de autores importantes como Bernardo Élis e Carmo Bernardes narram passagens que exemplificam e realçam os conflitos entre os policiais e a população. Conflitos marcados pela desconfiança e visão negativa frente aos representantes da lei. A memória do povo goiano esteve também permeada por diversos episódios nos quais a polícia mais causava medo e ansiedade do que garantia segurança e tranquilidade. O autor ressalta que a escassa polícia de Goiás teve que conviver - de igual para igual e, às vezes, até em certa desvantagem - com jagunços e bandoleiros contratados por coronéis. Nesse sentido, "procurava-se compensar a quantidade de policiais pela qualidade. Escolhiam-se os policiais mais pela valentia do que pela compostura moral" e, muitas vezes, "na briga entre as forças policiais e os grupos particulares armados a população ficava no meio, sendo, na maioria das vezes, espoliada por ambos os lados" (OLIVEIRA, 2012, p. 67).

Consequência dessa atuação policial - marcada por abusos e desmandos - é que ela própria foi responsável por uma sensação de desconfiança e temor na população. Reprimindo e combatendo mais ferozmente os movimentos populares do que os chefes de jagunços, quase nunca se metia em briga de peixe-grande, restando aos mais fracos e indefesos os resultados da prestação de serviços da Força Pública.

Ainda segundo Oliveira (2012), as dimensões do território tornavam o Governo algo distante e vago que, geralmente, fazia-se efetivamente presente apenas por meio de seus indesejados agentes (policiais, cobradores de impostos, recenseadores, dentre outros) que vinham tirar a população de sua quietude habitual. 
Destaca-se que, durante as décadas de 1920/30, três importantes episódios contribuíram para piorar ainda mais a visão negativa e o receio dos sertanejos goianos em relação à Força Pública: a temida Coluna Prestes - os revoltosos, como ficaram conhecidos -, que passou por Goiás em 1925 causando alvoroço e desconfiança; a Coluna Caiado, criada na intenção de defender o estado - sobretudo a capital - do assédio da Coluna Prestes; e, por fim, a Revolução Constitucionalista de 1932, a qual (como a Coluna Caiado) valeu-se do recrutamento voluntário da população civil a fím de robustecer suas tropas, provocando, como nos outros casos, rebuliço e fugas para o mato.

Com efeito, as Ânuas ${ }^{5}$ da casa de Campinas de 1925 tecem alguns comentários interessantes sobre a passagem dos revoltosos. Narram que após os momentos de tensão vividos pela população, "aos poucos foram todos voltando, quando constou que os rebeldes já estavam em Anápolis. A fuga tornou-se assunto então de risadas e chacotas". Riu-se da suposta covardia dos fujões, mas talvez, também, tentava-se exorcizar por meio da gozação o medo ainda latente após o recente sufoco. No final, o cronista conclui em tom realista "mas é fácil rir quando o perigo está longe!" (ÂNUAS, 1919-1931, p. 272). A Coluna Caiado, embora tenha utilizado todos os recursos disponíveis na época à caça da Coluna Prestes, não conseguiu encontrá-la. O cronista suspeitava que aquela aguardava que esta desocupasse uma comunidade para, só então, aparecer no local.

Os tais da Coluna Caiado sem instrução militar alguma, tremendo de medo diante dos revoltosos, que eram dados como valorossíssimos, corajosos até ao extremo, muito bem munidos etc, etc. andaram durante dois meses correndo atrás dos revoltosos sem nunca alcança-los porque só chegavam a uma povoação quando de lá se haviam retirado os rebeldes... (ÂNUAS, 1919-1931, p. 270-271).

A complicada realidade vivida pela comunidade civil e militar em Goiás neste período espelhava também o momento delicado da política e da sociedade brasileiras. A população, ao mesmo tempo que sofria os desmandos do Governo, como o recrutamento forçado, abuso do poder policial, impunidade, arbitrariedades administrativas etc., não restava inerte a algumas situações. Oliveira (2012) assinala que muitos grupos populares se formaram a fim de expulsar policiais, delegados ou juízes de suas localidades e que, embora grave, esse tipo de transgressão popular restava geralmente impune, denotando uma força repressora estatal ainda frágil. Dentre outros casos, cita aquele ocorrido em Bonfim em 1921, no qual o juiz de direito da comarca foi deposto e afastado da cidade pelo seu adversário político, apoiado por mais de cem cavaleiros armados.

Fica evidente que nem sempre as autoridades policiais cumpriam a contento seus papéis profissionais. Fatores como falta de capacitação, vocação, disposição ou meios adequados para tal foram algumas das razões para essas falhas. O jornal Santuario da Trindade ora as exaltava, ora as recriminava, ora, ainda, fazia as duas coisas, segundo as diversas ocasiões.

\footnotetext{
${ }^{5}$ Essas cartas/relatórios eram enviadas anualmente pelos superiores da vice-província ao governo provincial na Alemanha. As Ânuas começaram a ser traduzidas em 1991 e datilografadas a partir do ano seguinte.
} 


\title{
4 HOMENS DA LEI CONDENADOS PELO HUMOR
}

É possível afirmar que se o mister de delegados, juízes, policiais e advogados não teve muito espaço nas matérias sérias do Santuario da Trindade, na seção Anecdotas, em contrapartida, ele teve mais visibilidade. Nesse sentido, as piadas cujos alvos são os próprios homens da lei foram relativamente numerosas no jornal, com 48 ocorrências, e os ambientes cotidianos desses personagens - foros, tribunais, casernas, cadeias ou a rua - tornaram-se palco para as situações de troça.

Algumas indagações surgem à mente: como compreender a razão de esses agentes da força policial e judicial - grandes protetores legais da população - terem sido achincalhados com tal frequência e vivacidade nas piadas do jornal em questão? Os representantes da ordem, embora limitados por diversos fatores, como anunciado anteriormente, não deveriam ser respeitados e dignos de admiração, posto que muitas vezes arriscavam suas vidas para proteger a população, no combate à bandidagem? Por que então, ao contrário, eram alvo de chistes, geralmente pesados e insolentes? A hipótese que se apresenta na tentativa de responder tais questões é a do humor-deboche ou do rebaixamento, corroborada pela teoria do riso carnavalesco de Bakhtin.

Adianta-se que nas anedotas abaixo apresentadas, os agentes da lei foram alvo de tipos sociais que, literariamente, podem ser referidos como anti-heróis, mas que, para expressar uma maior coerência com a teoria do rebaixamento de Bakhtin, serão aqui denominados heróis baixos.

\footnotetext{
Coexistindo em espaços não formais, invariavelmente, não pertencentes à nobreza, embora passeiem por eles em certos momentos, os heróis baixos são assim classificados por não fazerem parte da alta sociedade, não deterem, a priori, o poder da fala ou desconhecerem a escrita. Mesmo os textos publicados em primeira pessoa são atribuições de um narrador à voz desses heróis. [...] Os heróis baixos habitam o humor. Seu discurso, carregado de ironia, é propagado através da comédia, diluído pelo riso, encontrado nos chistes e gracejos que saem de sua boca. (NASCIMENTO NETO, 2014, p. 36)
}

Os heróis baixos podem assumir, na realidade e na criação estética, diferentes formatos, como a figura do bufão, do palhaço e do malandro. Geralmente não possuem virilidade, poder e dinheiro e precisam valer-se da esperteza para sobreviver no mundo. Numa das piadas, um desses heróis baixos se depara com um juiz, o paradigma da manutenção da ordem social.

\author{
No Jury. \\ O juiz, paternal, ao réo: \\ - Espero que seja a ultima vez que o veja neste recinto. \\ O réo, com interesse: \\ - Como? Pois V. Excia. pretende aposentar-se? \\ (SANTUARIO DA TRINDADE, 1930, n. 353, p. 3) ${ }^{6}$
}

\footnotetext{
${ }^{6}$ A linguagem das anedotas corresponde ao original da época. 
O protagonista da piada assemelha-se à figura do malandro ${ }^{7}$, na sua convicção inabalável de viver uma vida de transgressão. Encarnando um típico "cinismo rabelaisiano" (BAKHTIN, 1999, p. 126), o réu, incorrigível, devolve a leve reprimenda do magistrado com uma pergunta irônica sobre sua eventual aposentadoria, já que ele mesmo não pretendia abandonar a profissão, não obstante a iminência de ser ulteriormente capturado. É desnecessário asseverar que, obviamente, a população leitora do jornal - imagine seus editores! - era fortemente contrária à prática de crimes e concordasse que seus executores deveriam ser punidos com rigor. Então, possivelmente, o humor da piada não deriva das inferências que o leitor deverá fazer para compreendêla, ou seja, que o réu está anunciando sub-repticiamente que outros crimes viriam a acontecer, mas sim do deboche do acusado que, em tom propositalmente ingênuo, achincalha ao mesmo tempo o sistema repressor do Estado - declaradamente ineficiente -, e a pessoa do juiz, seu representante imediato.

Acredita-se que a anedota possa ter agradado e feito sentido ao público, porque na vida real, e sobretudo no contexto da época, símile resposta seria quase impensável para uma pessoa de bem, exceto se camuflada por piada que diz sem querer dizer e fala por vias reversas. Ou, como sugere a teoria bakhtiniana sobre a inversão carnavalesca: o juiz tornou-se vítima do réu.

O malandro, como a maioria dos heróis baixos populares, se sentia à vontade no mundo da rua ou da praça pública, "o ponto de convergência de tudo que não era oficial" e que "gozava de um direito de 'extraterritorialidade' no mundo da ordem e da ideologia oficial” (BAKHTIN, 1999, p. 132). O Tribunal de Júri era o antípoda da praça pública, um lugar altamente hierarquizado, onde as regras de etiqueta e a linguagem formal sufocavam o integrante da cultura popular. Assim, no caso da piada acima transcrita, o malandro, não podendo valer-se dos insultos, dos xingamentos, das gírias, finge aceitar a hierarquização, usando o pronome de tratamento "vossa excelência" para demonstrar uma falsa preocupação com o futuro profissional do juiz.

Além dos magistrados, os militares constituíam outra personalidade antagônica à irreverência da cultura popular. Roberto DaMatta (1997) analisa a representação dos militares na cultura brasileira a partir da figura do caxias, termo derivado de um dos mais importantes heróis históricos brasileiros - o Duque de Caxias -, mas que ganhou um sentido crítico entre os populares. O caxias expressa

uma outra leitura do mundo, definindo-o por suas regras, leis, decretos, regulamentos, portarias e regimentos, isto é, pela presença nítida e poderosa da totalidade materializada na lei e na regra, em oposição ao mundo individualizado das pessoas (DAMATTA, 1997, p. 264).

A piada seguinte explora o conflito entre o sentimento individual de um atrapalhado sargento e a necessidade de mostrar-se respeitoso ao sistema hierárquico militar.

\footnotetext{
${ }^{7}$ Seguindo a metodologia utilizada por Roberto DaMatta (1997, p. 263) em Carnavais, Malandros e Heróis, o termo "malandro" é empregado, aqui, como um tipo social e não se reduz ao estereótipo do malandro carioca. Assim, o malandro estaria às margens das regras formais, "fatalmente excluído do mercado de trabalho", geralmente possui aversão à ética do trabalho e um jeito individualizado de falar e de se vestir.
} 
No quartel.

- Sargento!

- Prompto, seu capitão.

- Porque castigou o soldado 81 ?

- Porque o apanhei querendo arremedar V. S. diante da companhia.

- Arremedar-me! Mas que faria esse patife?

- Repetia as vozes de commando, berrando como uma besta!

(SANTUARIO DA TRINDADE, 1931, n. 390, p. 3)

Este chiste trata de um problema interno às escolas militares. Nele, porém, o efeito humorístico decorre de um ato falho do sargento, ou seja, sua fala intencional sofreu uma interferência - que exprimiu sua vontade inconsciente - não intencional. Vale dizer que o competente militar, ao explicar os motivos da punição exemplar feita ao soldado debochado, acabou por debochar, ele mesmo, do superior. O protagonista dessa piada não se parece com o malandro da piada anterior, até porque dificilmente um malandro subiria na hierarquia militar. O sargento lembra mais um parvo, cuja estupidez faz com que a sua determinação em defender a honra do capitão diante dos ultrajes do soldado 81 (esse, sim, um autêntico malandro) acabe por revelar, sem perceber, que concordava com a opinião do soldado segundo a qual o capitão comandava "berrando como uma besta!".

Nas duas piadas referidas, há uma espécie de inversão da ordem social e hierárquica que coloca os figurões do poder, no caso o juiz e o capitão, à mercê do riso dos mais fracos, do populacho. É a revanche por meio do bom-humor que os faz escapar, momentaneamente, de suas condições vulneráveis. Esse humor, contudo, parece não visar à mudança social, mas somente a algum tipo de alívio proporcionado pelo divertimento, como sugere Bakhtin (1999).

Em outras duas anedotas, os protagonistas estão numa situação constrangedora, ao serem interrogados pela polícia.

\author{
$\mathrm{Na}$ chefatura de policia. \\ - O réu tem parentes proximos? \\ - Não, senhor. \\ - Não disse, ha pouco, que tinha pais e irmãos. \\ - Mas não estão proximos; vivem em Manaus. \\ (SANTUARIO DA TRINDADE, 1925, n. 121, p. 4) \\ PERANTE A POLICIA: \\ Commissario da policia: Onde moras? \\ Preso: Em nenhuma parte. \\ E o senhor? - pergunta ao companheiro d'esse. \\ No segundo andar da casa desse. Mas não ha elevador. \\ (SANTUARIO DA TRINDADE, 1927, n. 234, p. 4)
}

Como bons malandros, os protagonistas desses dois chistes utilizam a irreverência para tripudiar sobre as autoridades policiais. Assim como os militares, os policiais são vistos geralmente como um tipo que "encarna aquela complexa combinação de seguidor 
das leis, competência burocrática, lealdade absoluta, patriotismo honesto e crédulo" (DAMATTA, 1997, p. 269). E vale ressaltar que a conduta policial é também normatizada por um cerceamento do comportamento a partir de símbolos exteriores, como medalhas, uniformes, armas e continências.

Já os malandros se situam num universo marcado pela improvisação e a exteriorização dos sentimentos. No caso dessas anedotas, dominados pelo aparelho coercitivo do Estado, resta aos heróis baixos tentar transformar os policiais em alvos de chacota, realizando, assim, uma pequena vingança: na primeira, o réu brinca com as palavras, finge desconhecer a ambiguidade do termo próximo, imputando-lhe apenas um significado relacionado à distância geográfica; e na segunda, os presos enredam o comissário de polícia num paradoxo filosófico, já que não é possível morar num segundo andar de uma casa situada em lugar algum. O preso, em ato insolente, dá o golpe final no comissário ao afirmar que a casa não tinha elevador.

Dentro do complexo contexto goiano do período, a inserção dessas anedotas que tripudiavam sobre os homens da lei deixa claro o poder do humor como uma possível válvula de escape, muito bem utilizada pelos editores do jornal Santuario da Trindade. Afinal, debochar do militar, delegado, juiz ou policial era algo que poderia minimizar as agruras dos desmandos cotidianos, é a ideia do "mundo virado de cabeça para baixo", como descreve Burke (1989, p. 212) em relação ao carnaval popular da Idade Moderna. Assim, assinala-se que o periódico soube utilizar muito bem as anedotas como estratégia discursiva a fim de atrair o público leitor, dando-lhe pano pra manga para triunfar mesmo que somente na fantasia - sobre as autoridades legais.

As piadas, nesse sentido, exibem as mais variadas situações. Apresentam réus que, fazendo-se de desentendidos, dificultam sua identificação, a exemplo também de dois outros chistes acima apresentados.

\author{
Na Delegacia: \\ Juiz: - Qual é o seu estado? \\ Réo: - Um tanto febril; não pude dormir esta noite toda; mas, em todo caso, agradeço-lhe \\ muito o interesse que se digna ter por minha humilde pessoa.
}

(SANTUARIO DA TRINDADE, 1927, n. 227, p. 3)

Nessa anedota, o recurso de linguagem que produz o efeito humorístico é fonte comum de diversas outras: a polissemia dos vocábulos, nesse caso específico a da palavra estado. Supõe-se que, considerados o local e a circunstância, o juiz tenha querido indagar a origem geográfica ou o estado civil do réu, o qual, astuciosamente, toma a pergunta do magistrado em um outro sentido: como uma manifestação de gentileza e preocupação por seu estado de saúde. Caso análogo é o da piada a seguir, na qual o humor deriva da construção de uma frase ambígua. Assim, a advertência do guarda em relação a o vagabundo não poder dormir "num banco d'estes" causou o equívoco de interpretação do sujeito, que responde a seu arguidor como se tivesse ouvido que não deveria dormir ali porque merecia repousar em um lugar melhor que aquele banco especifico. 
Um guarda-civil encontra à noite um vagabundo deitado num banco da Avenida Beira-Mar.

Acerca-se d'elle e diz:

- Você não pòde dormir num banco d'estes!

- Eu não sou de luxo! è duro mas serve. Agradeço a attenção.

E o vagabundo estira-se de novo.

(SANTUARIO DA TRINDADE, 1925, n. 133, p. 4)

Nesta abaixo o delinquente escamoteia a realidade procurando se safar das encrencas.

Deante do delegado.

- Você está acusado, de ter roubado o burro.

- Não roubei, não sr. delegado; achei-o.

- Mas não viu no burro as letras B. S. D., indicando o dono delle?

- Vi, por isto mesmo é que o levei para casa. Pensei que aquellas letras queriam dizer: burro sem dono.

(SANTUARIO DA TRINDADE, 1922, n. 8, p. 4)

O jogo humorístico dessa anedota encontra-se na liberdade de leitura que o "acusado" toma diante das iniciais B. S. D., presentes no lombo do burro. De forma dissimulada, alega boa-fé na leitura de tais letras como sendo "burro sem dono", o que legitimaria seu direito sobre a posse do animal.

Bakhtin (1999, p. 78) destaca que o humor carnavalesco medieval tinha uma função libertadora. Enquanto a violência e a repressão é séria, "o riso não impõe nenhuma interdição, nenhuma restrição". O riso é uma forma de dominar o medo. Um exemplo é a situação trágica do protagonista na piada seguinte:

Pio voto.

Juiz ao condemnado: - O senhor foi condemnado á morte. Tem ainda um ultimo desejo?

Condemnado: - Sim, senhor juiz, eu desejava muito que o senhor estivesse em meu logar.

(SANTUARIO DA TRINDADE, 1929, n. 316, p. 3)

O réu, condenado à pena capital, não parece desesperado. Ele simplesmente afirma com polidez - utilizado inclusive a respeitosa expressão senhor juiz - que o seu desejo era que seu algoz morresse em seu lugar. A piada desnuda a ironia da situação de oferecer uma falsa benevolência a alguém que foi condenado à morte. Isso remete a uma anedota apresentada por Freud (1905, p. 2003), em seu estudo sobre o chiste, na qual

\footnotetext{
Um vagabundo que estava sendo levado à execução em uma segunda-feira, comentou: 'É, a semana está começando otimamente'. Este é efetivamente um chiste, já que o comentário é bem adequado em si mesmo, mas por outro lado está deslocado de uma maneira absurda, já que para o próprio sujeito não haveria eventos ulteriores naquela semana.
}

Freud afirma que anedotas desse tipo são exemplos da grandeza do humor. O fato de o indivíduo ter condições de fazer piada diante de uma situação tão trágica demonstra um relaxamento do espírito diante das tensões. Ao fazer piada perante o infortúnio, os protagonistas dessas duas piadas venceram - ao menos temporariamente - o medo. 
Em outro caso, bem distante de uma condenação à morte, o protagonista sente-se tão à vontade ao ponto de partir para a ofensiva, procurando atingir alguma vulnerabilidade física de seu algoz:

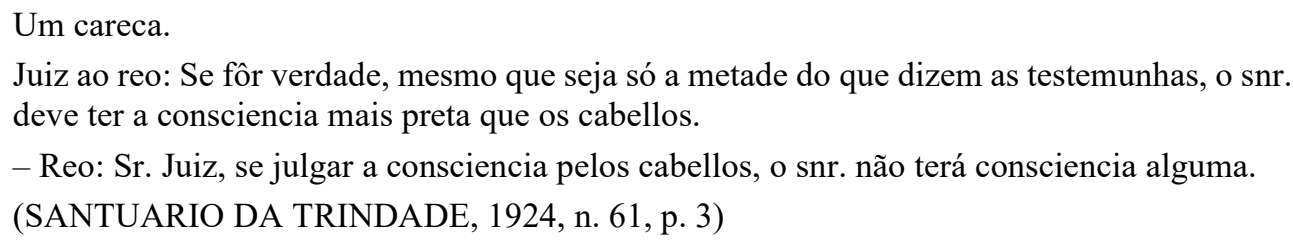

O réu da piada acima se comporta como quem faz sátira, gênero literário muito cultivado na Roma Antiga. Minois (2003, p. 91) definiu a sátira como "uma sabedoria rústica expressa de maneira escarnecedora" que imita para destruir, como faz o protagonista da piada, que destrói o argumento metafórico do infeliz juiz.

Um herói baixo, com uma língua perigosamente ferina, é o bêbado. Na piada a seguir, por exemplo, a situação hilária é consequência da resposta audaciosa de uma testemunha que se apresenta alcoolizada em uma audiência de tribunal. Contudo, aqui, o prévio conhecimento da frase latina é necessário para que a piada atinja seu efeito cômico:

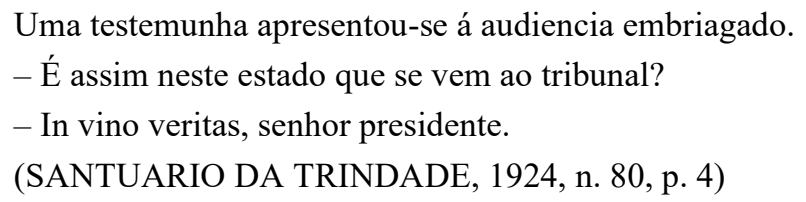

No vinho está a verdade, alega a testemunha, concordando com os antigos romanos para os quais certa embriaguez contribuía à soltura da língua e à consequente aparição da verdade. O bêbado desempenha o papel de um bufão, personagem cômico muito importante nas cortes absolutistas europeias. De acordo com Minois (2003, p. 285), "seu papel é expressar a verdade pelo riso, pela derrisão, chamando as coisas pelo seu nome, ou seja, chamando as sublimes 'razões de estado' pelo que elas são na verdade: vulgares cálculos de interesse". O bêbado, como o bufão, situa-se numa linha ambígua, entre a sabedoria e a idiotice, entre a razão e a ignorância. Por isso não respeita os interstícios sociais. Bakhtin (1999, p. 147) destaca que, para Rabelais, o vinho é "símbolo da verdade livre e alegre", por isso, muito superior ao azeite, "símbolo da sabedoria devota".

Vale assinalar que o bêbado não é um personagem exclusivo da cultura popular, já que as classes altas também não se furtam ao prazer etílico, mas é um personagem tipicamente carnavalesco, uma figura das festas, das feiras e das ruas. Contudo, o protagonista da piada abaixo demonstra desconhecer os limites dessa interdição geográfica da bebedeira.

\footnotetext{
No quartel.

O tenente, percorrendo o quartel, encontra um soldado em estado de embriaguez completa. Reprehende-o fortemente dizendo: - Estás bebado! é falta grave para um soldado; sabes, qual è a tua pena?

Soldado: - Pena! não tenho pena alguma, antes pelo contrario sinto-me alegre agora como nunca.
}

(SANTUARIO DA TRINDADE, 1929, n. 301, p. 3) 
A característica textual que provoca o efeito humorístico dessa piada (caso semelhante ao de outra anteriormente apresentada) gira em torno da polissemia da palavra pena. O soldado transgressor altera o significado discursivo de pena, como castigo e punição, proposta pelo tenente, por pena no sentido de tristeza e desgosto. A piada explica que a embriaguez é "falta grave para um soldado", mas teria sido também para patentes mais altas? Fato é que a ação e resposta do soldado servem a realçar certa subversão da ordem. O soldado não tem medo da punição, ao contrário, sequer compreende a ameaça do tenente, pois se sente completamente tomado pela alegria.

Assim, o povo comum, não dispondo de ulteriores vias de fuga contra os desmandos e exageros vindos de cima, das autoridades, muitas vezes tirou a desforra por meio do escárnio, na vida real. E aqui a teoria bakhtiniana alerta para o rebaixamento, o grotesco. Nesse sentido, juízes, policiais, delegados foram vencidos, ao menos simbolicamente, pelo prazer do deboche e do riso popular nas piadas do jornal Santuario da Trindade. O processo de disciplinarização das práticas e costumes populares pelo Estado encontrou uma resistência direta (motins, sedições, revoltas), mas também uma resistência de caráter discursivo, como é o caso das piadas analisadas neste artigo.

\section{CONSIDERAÇÕES FINAIS}

As piadas sobre juízes, delegados, policiais e oficiais graduados do Exército constituem um material raro e rico para estudar a maneira de pensar dos integrantes da cultura popular em relação aos representantes das instituições repressoras da sociedade. O humor, por meio da manipulação da linguagem, subverte as hierarquias e possibilita momentos de prazer aos indivíduos. Assim, as piadas podem ser vistas como uma forma de expressão discursiva que faz uso de uma linguagem condensada, substitutiva e indireta, mascarando um desejo ou expondo verdades que se opõem às pressões sociais.

Diante das autoridades policiais, jurídicas e militares, o indivíduo comum é compelido a ter uma postura subserviente e a utilizar uma linguagem ritualista e formalista: sim senhor, não senhor, vossa excelência, doutor delegado. Nas abordagens policiais, nos depoimentos aos delegados e aos juízes, o "homem do povo" é obrigado a contrariar sua prática cotidiana e a seguir os padrões discursivos da cultura oficial, a ser sério em meio a gente e instituições sérias.

Nesse sentido, as piadas sobre as autoridades são mais do que momentos de descontração. A atitude desrespeitosa dos protagonistas das anedotas citadas nesse trabalho torna-se uma revanche simbólica de todas as situações vexatórias que foram obrigados a suportar. As piadas configuram-se na oportunidade de rebaixar o delegado, o juiz, o general, o policial, a uma situação ridícula e vexatória. De deixá-los constrangidos e envergonhados. É uma utopia de inversão social na qual os mais fracos assumem o controle dos ritos sociais.

Tais piadas, desse modo, podem ser consideradas exemplos do riso libertador das camadas populares, presente na teoria de Bakhtin. Esse riso era capaz de fazer com que o indivíduo pudesse "estabelecer relações novas, verdadeiramente humanas, com seus semelhantes" e, o que é muito surpreendente, fazer com que "[a] alienação 
desapare[cesse] provisoriamente" (BAKHTIN, 1999, p. 9). Parece que o marxismo de Bakhtin se inspira mais em Groucho $\operatorname{Marx}^{8}$ do que em Karl Marx, em sua valorização do riso como libertador das coerções sociais.

O jornal Santuario da Trindade, durante quase dez anos de circulação pelas cidades goianas, usou os discursos humorísticos como forma de aproximação com as camadas populares. E, coerente com seus princípios católicos, estimulava seus leitores a serem ordeiros e respeitosos com as autoridades constituídas. Contudo, a seção de piadas era, usando uma terminologia bakhtiniana, um verdadeiro carnaval, onde quase tudo era permitido. Ao contrário das outras páginas do periódico, a parte humorística se tornava o espaço da subversão, da gargalhada e da chacota. Agradava às camadas populares e, supostamente, agradava aos editores do jornal e - quem sabe - uma autoridade que tivesse consciência de que rir de si mesmo pode ser a melhor forma de enfrentar as agruras da vida.

\section{REFERÊNCIAS}

BAKHTIN, M. A cultura popular na Idade Média e no Renascimento: o contexto de Francois Rabelais. Brasília: UnB, 1999.

BURKE, P. Cultura popular na Idade Moderna. São Paulo: Companhia das Letras, 1989.

DAMATTA, R. Carnavais, malandros e heróis: para um sociologia do dilema brasileiro. Rio de Janeiro: Rocco, 1997.

ÉLIS, B. A Enxada. In: TELES, G. M. (Org.). Os melhores contos de Bernardo Élis. São Paulo: Global, 2003.

GALVÃO, A. M. C. "Um remédio para a alma”: o risível em Goiás no jornal Santuário da Trindade (1922-1931). 2015. 166 f. Dissertação (Mestrado em Ciências Sociais e Humanidades) - Programa de Pós-graduação em Ciências Sociais e Humanidades, Universidade Estadual de Goiás, Anápolis, 2015. Disponível em: http://cdn.ueg.edu.br/source/teccer/conteudo/10606/dissertacao_Andreia.pdf

FREUD, S. Os chistes e sua relação com o inconsciente. In: FREUD, S. Obras completas. v. 8 (1905). p. 1830-2007. Disponível em: <http://lelivros.gratis/book/obras-completas-dr-sigmund-freud/>. Acesso em: 4 mar. 2014.

HALBWACHS, M. A memória coletiva. Trad. Beatriz Sidou. São Paulo: Centauro, 2003.

MINOIS, G. História do riso e do escárnio. Trad. Maria Elena O. Ortiz Assumpção. São Paulo: Editora UNESP, 2003.

NASCIMENTO NETO, J. E. Perambulanças de João Grilo: do pícaro lusitano ao malandro brasileiro, as peripécias do(anti-)herói popular. 2014. 393 f. Tese (Doutorado Interinstitucional (Dinter)) - Programa de Pós-Graduação em Letras, Pontifícia Universidade Católica do Rio Grande do Sul, Porto Alegre, 2014. (Convênio com a Universidade do Estado da Bahia).

OLIVEIRA, E. C. Chacinas, combates \& massacres: medo e violência em Goiás. Goiânia: PUC-GO e Kelps, 2012.

PALACIN, L. Coronelismo no extremo Norte de Goiás. Goiânia: UFG, São Paulo: Loyola, 1990.

PESAVENTO, S. Em busca de uma outra história: imaginando o imaginário. Revista Brasileira de História, São Paulo, v. 15, n. 29, p. 9-27, 1995.

POSSENTI, S. Os humores da língua: análises linguísticas de piadas. Campinas, SP: Mercado de Letras, 1998.

SALIBA. E. T. Raízes do riso: a representação humorística na história brasileira - da Belle Époque aos primeiros tempos do rádio. São Paulo: Companhia das Letras, 2002.

\footnotetext{
${ }^{8}$ Groucho Marx, nome artístico de Julius Henry (1890-1977), um dos quatro componentes do grupo chamado "Irmãos Marx", comediantes que fizeram grande sucesso nos Estados Unidos.
} 
FONTES DOCUMENTAIS

ÂNUAS da Vice-Província de São Paulo, v. II (1919-1931).

BRASIL. Recenseamento de 1920. Disponível em:

http://www.seplan.go.gov.br/sepin/pub/GoDados/2003/demografia.htm. Acesso em: 23 nov. 2014.

Deante do delegado. Santuario da Trindade, n. 8, Campinas, p. 4, 7 out. 1922.

Na chefatura de policia. Santuario da Trindade, n. 121, Campinas, p. 4, 22 ago. 1925.

Na delegacia. Santuario da Trindade, n. 227, Campinas, p. 3, 22 out. 1927.

No jury. Santuario da Trindade, n. 353, Campinas, p. 3, 03 maio 1930.

No quartel. Santuario da Trindade, n. 301, Campinas, p. 3, 20 abr. 1929.

No quartel. Santuario da Trindade, n. 390, Campinas, p. 3, 28 fev. 1931.

Perante a policia. Santuario da Trindade, n. 234, Campinas, p. 4, 10 dez. 1927.

Pio voto. Santuario da Trindade, n. 316, Campinas, p. 3, 10 ago. 1929.

Reflexões. Santuario da Trindade, n. 38, Campinas, p. 1, 01 dez. 1923.

Um careca. Santuario da Trindade, n. 61, Campinas, p. 3, 31 mai. 1924.

Um guarda-civil... Santuario da Trindade, n. 133, Campinas, p. 4, 21 nov. 1925.

Uma testemunha... Santuario da Trindade, n. 80, Campinas, p. 4, 18 out. 1924

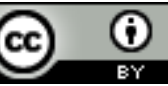

Este texto está licenciado com uma Licença Creative Commons Atribuição 4.0 Internacional. 